It is suggested that the criteria for assessing what is an abnormal neurological response may be refined by reference to the responses of our low and high risk groups.

My thanks are due to Professor L. A. Joosse and Professor B. S. ten Berge, of the Department of Obstetrics, University of Groningen, for their interest and co-operation over the many years of this study. I am also indebted to my co-workers, Drs. J. D. Beintema, J. Dijkstra, A. v.d. Gaag, W. Lawant, and B. C. L. Touwen, for their part in collecting the data. Without the great assistance of Dr. D. Smits, director of the Computer Centre of the university, and Dr. R. Wippler and Mrs. J. H. van Dijk-v.d. Horst the dataprocessing would have been impossible. I want to express my warm appreciation for the help of Dr. S. J. Hutt in the preparation of the manuscript. This study was supported by a grant from the Association for the Aid of Crippled Children, New York.

\section{RBFERENCES}

Apgar, V. (1966). Pediat. clin. N. Amer., 13, 645.

Butler, N. R., and Bonham, D. G. (1963). Perinatal Mortality. Edinburgh and London.
Clark, D. B., and Anderson, G. W. (1961). 7. Neuropath. exp. Neurol., 20, 275 .

Dargassies, S. Saint-Anne (1962). Biol. Neonat. (Basel), 4, 174.

Debré, R., Bargeton, E., Mozziconacci, P., and Habib, R. (1955). Arch franç. Pédiat., 12, 673.

Drage, J. S., and Berendes, H. (1966). Pediat. clin. N. Amer., 13, 635.

Graham, F. K. (1956). Psychol. Monogr., 70, No. 20-21, p. 1.

- Matarazzo, R., and Caldwell, B. M. (1956). Ibid., 70, No. 20-21, p. 17.

Pennoyer, M. M., Caldwell, B. M., Greenman, M., and Hartmann, A. F. (1957). F. Pediat., 50, 177.

De Haas-Posthuma, J. H. (1962). Perinatale Sterfte in Nederland. Onderzoek naar Factoren, die de Perniatale Sterfte Beinvloeden. Assen.

Malamud, N. (1959). f. Neuropath. exp. Neurol., 18, 141.

Morf, E., and Bretscher, J. (1966). Gynaecologia (Basel), 161, 211.

Norman, A. P. (1956). Brit. med. f., 1, 37.

Prechtl, H. F. R. (1965). Proc. roy. Soc. Med., 58, 3.

- and Beintema, D. (1964). The Neurological Examination of the Full-term Newborn Infant. Little Club Clinics in Developmenta Medicine No 12. London.

and Diikstra, J. (1960). In Prenatal Care, p. 222, Groningen.

Ranck, J. B., and Windle, W. F. (1959). Exp. Neurol., 1, 130.

Windle, W. F. (1960) Pediatrics, 6, 565.

- De Ramirez De Arellano, M. I. R., Ramirez De Arellano, M., and Hibbard, E. (1961). Rev. neurol., 105, 142.

\title{
Concentration of Methoxyflurane for Obstetric Analgesia by Self- administered Intermittent Inhalation
}

\author{
VALERIE MAJOR, ${ }^{*} \dagger$ F.F.A. R.C.S.; MICHAEL ROSEN,* F.F.A. R.C.S. \\ WILLIAM W. MUSHIN,* F.R.C.S., F.F.A. R.C.S.
}

Brit. med. F., 1967, 4, 767-770

\begin{abstract}
Methoxyflurane has been shown to possess advantages over trichloroethylene as an obstetric analgesic (Major, Rosen, and Mushin, 1966). In that initial study we varied the concentration of both vapours continuously, with the aim of giving each patient the best possible analgesia without undesirable sideeffects. The design of the trial made it possible (by analysing the continuous recordings of the inhaled concentrations of methoxyflurane) to deduce that for intermittent use a single fixed concentration of the drug would prove adequate and that this would be $0.35 \%$. The present trial tests the validity of these predictions.
\end{abstract}

\section{Method}

Two concentrations of methoxyflurane in air $(0.35 \%$ and $0.25 \%$ ) were compared. These were chosen because observations in our first trial indicated that patients tended to become unacceptably drowsy at concentrations higher than $0.35 \%$. This decision has been confirmed by observations of some patients in this trial who were studied at a higher concentration $(0.45 \%)$.

Methoxyflurane was given from identical Penlon P.D.V. vaporizers, as these were the most accurate "draw-over" vaporizers available to us for this drug. Each was modified so that only one predetermined concentration could be given. The vaporizers were calibrated by us with a katharometer, using a Beaver ventilator as a dummy patient, and the concentrations were checked frequently throughout the trial. Before being used by a patient each vaporizer was flushed with oxygen for at least three minutes to clear the "dead" space.

- Department of Anaesthetics, Welsh National School of Medicine,
Cardiff. † Abbott Research Fellow.
The day on which each concentration was used was previously randomized. Though an anaesthetist was present as an assessor throughout the inhalation, the conduct of analgesia was left to the midwife, so that the conditions were as near "normal" as possible. Inhalation was therefore started at the midwife's discretion, usually towards the end of the first stage of labour. A record was kept of the dose and time of administration of other drugs given during labour; no direction or restriction was made regarding their use. Assessments were made separately by an anaesthetist, by the midwife, and by the mother.

The same anaesthetist was present for all cases and made continuous assessments. For the full details of the method of assessment readers are referred to our previous paper (Major et al., 1966). In brief, assessments are made of the mother's response to contractions, her level of consciousness, and any restlessness between contractions. The anaesthetist's observations are plotted to show the proportion of time during the whole period of observation for which each of the three factors is deemed "satisfactory." The periods for which all factors are satisfactory are calculated and expressed as a percentage of the total duration of inhalation.

As in the previous trial, the midwife, for whom the trial was blind, gave her assessment just after delivery with respect to the degree of analgesia, the drowsiness of the patient, and the restlessness of the patient. The mother was questioned twice-15 minutes after delivery and then 36 to 48 hours later. The questions at 15 minutes were slightly modified in this trial. She was asked: "Do you consider that what you had to breathe helped you ?"; "Do you feel drowsy ?"; "Did you drift off at all ?" ; and "Could you do what we asked?" At the second visit other questions were asked regarding nausea, vomiting, memory, and smell. 
Measurements of ventilation were made in some mothers by means of a Wright respirometer and a stop-watch. The baby was assessed by the Apgar score at one minute, and by noting the time to the onset of regular respiration.

\section{Results}

Forty-three patients were given inhalational analgesia. Twenty-three had $0.35 \%$ methoxyflurane (11 primigravidae, 12 multigravidae-19 spontaneous vertex deliveries) and 20 had $0.25 \%$ methoxyflurane (10 primigravidae, 10 multigravidae -18 spontaneous vertex deliveries).

\section{Duration of Inhalation}

The shortest period of inhalation was 16 minutes and the longest 6 hours 30 minutes. The mean duration for $0.35 \%$ methoxyflurane ( 0.35 group) was 1 hour 30 minutes, and for $0.25 \%$ methoxyflurane (0.25 group) 1 hour 26 minutes $(\mathbf{P}>0.70)$. The groups appear similar in this respect.

\section{Observations by Anaesthetist}

All Factors Satisfactory (Table 1).-The percentage of time of inhalation for all factors satisfactory was determined for each patient. The mean for each group was calculated. The 0.35 group was satisfactory for significantly longer $(72.7 \%)$ than the 0.25 group $(55.5 \%)$.

TABLE I.-Percentage of Duration of Inhalation Regarded as Satisfactory

\begin{tabular}{|c|c|c|c|}
\hline \multirow[b]{2}{*}{ Factor Studied } & \multicolumn{2}{|c|}{$\begin{array}{l}\text { Mean Percentage of } \\
\text { Time Satisfactory }\end{array}$} & \multirow[b]{2}{*}{$\begin{array}{c}\text { Significance } \\
(t \text { test })\end{array}$} \\
\hline & $\begin{array}{c}0.35 \% \\
\text { Methoxy- } \\
\text { flurane } \\
\text { (23 patients) }\end{array}$ & $\begin{array}{c}0.25 \% \\
\text { Methoxy- } \\
\text { flurane } \\
\text { (20 patients) }\end{array}$ & \\
\hline $\begin{array}{l}\text { All factors satisfactory } \\
\text { Reaction to contraction satisfactory } \\
\text { Level of consciousness satisfactory } \\
\text { Restlessness satisfactory .. }\end{array}$ & $\begin{array}{c}72 \cdot 7 \\
72 \cdot 8 \\
100 \\
98 \cdot 9\end{array}$ & $\begin{array}{c}55 \cdot 5 \\
55 \cdot 5 \\
100 \\
94 \cdot 6\end{array}$ & $\begin{array}{l}\mathrm{P}<0.05 \\
\mathrm{P}<0.05 \\
\mathrm{P}<0.10\end{array}$ \\
\hline
\end{tabular}

Reaction to Contraction (Table I).-The 0.35 group was significantlv better in this respect $(72.8 \%)$ than the 0.25 group $(55.5 \%)$.

Level of Consciousness (Table I).-All the patients were satisfactory.

Restlessness between Contractions (Table i).-Only six mothers showed any restlessness-two received $0.35 \%$ and four received $0.25 \%$ methoxyflurane. The 0.35 group was satisfactory for slightly longer than the 0.25 group.

Effect of Duration of Inhalation on All Factors Satisfactory (Table II).- The effect of the duration of inhalation was studied by dividing each labour into consecutive half-hour periods starting five minutes after the beginning of inhalation. The mean time for the 0.35 group was higher for each half-hour period, and the difference between the two groups is significant in the first half-hour.

Effect of Progress of Labour on All Factors Satisfactory (Table II).- The effect that the progress of labour had on all factors satisfactory was examined for the half-hour period immediately preceding delivery: the mean time for the 0.35 group was significantly higher.

TABLE II.-Effects of Duration of Inhalation and Progress of Labour on All Factors Satisfactory

\begin{tabular}{|c|c|c|c|c|}
\hline \multirow{3}{*}{ Group } & \multicolumn{4}{|c|}{ Mean Percentage of Time All Factors Satisfactory } \\
\hline & \multicolumn{3}{|c|}{ Half-hour Period of Inhalation } & \multirow{2}{*}{$\begin{array}{l}\text { Half-hour } \\
\text { Preceding } \\
\text { Delivery }\end{array}$} \\
\hline & 1st & 2nd & 3 rd & \\
\hline $\begin{array}{l}0.35 \\
0.25\end{array}$ & $\begin{array}{l}80.3 \\
59 \cdot 4\end{array}$ & $\begin{array}{l}76.5 \\
55.3\end{array}$ & $\begin{array}{l}71 \cdot 4 \\
46.6\end{array}$ & $\begin{array}{l}79.5 \\
53.2\end{array}$ \\
\hline Significance ( $t$ test) & $P<0.05$ & $P<0.20$ & $P>0.20$ & $P<0.02$ \\
\hline
\end{tabular}

Effect of Pethidine on All Factors Satisfactory (Table III).Nearly the same proportion of patients in each group received pethidine during the four hours immediately preceding the start of inhalation (13 out of 23 patients in the 0.35 group and 12 out of 20 in the 0.25 group). The difference in the assessment between the two groups does not appear to be due to the administration of pethidine.

Table III.-Effect of Pethidine on All Factors Satisfactory

\begin{tabular}{|c|c|c|c|}
\hline \multirow[b]{2}{*}{ Group } & \multicolumn{2}{|c|}{$\begin{array}{l}\text { Mean Percentage of Time All } \\
\text { Factors Satisfactory }\end{array}$} & \multirow{2}{*}{$\underset{(t \text { test })}{\text { Significance }}$} \\
\hline & $\begin{array}{l}\text { Pethidine during } \\
4 \text { hours Preceding } \\
\text { Inhalation }\end{array}$ & $\begin{array}{l}\text { No Pethidine dur- } \\
\text { ing } 4 \text { hours Pre- } \\
\text { ceding Inhalation }\end{array}$ & \\
\hline $\begin{array}{l}0.35 \\
0.25\end{array}$ & $\begin{array}{l}74 \cdot 1 \\
54 \cdot 1\end{array}$ & $\begin{array}{l}71 \cdot 0 \\
58 \cdot 0\end{array}$ & $\begin{array}{l}P>0.70 \\
P>0.70\end{array}$ \\
\hline
\end{tabular}

\section{Opinion of Midwife}

The midwives thought the analgesia "complete" in $31 \%$ of the mothers in the 0.35 group and in $5 \%$ of the mothers in the 0.25 group. This difference is significant (Table IV).

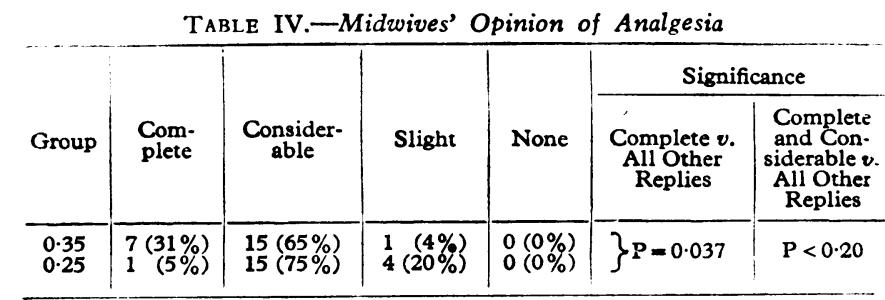

One patient ( $4 \%$ ) of the 0.35 group was graded as restless, and four $(20 \%)$ of the 0.25 group. The restless mother in the 0.35 group was graded as having " considerable" pain relief, whereas the four in the 0.25 group were also graded as having "slight" analgesia.

No mother in either group was thought by the midwives to be "too drowsy."

\section{Opinion of Mother}

Assessment of Pain Relief at 15 Minutes after Delivery (Table V).-Pain relief was thought to be "complete" in $43 \%$ of the 0.35 group and in $15 \%$ of the 0.25 group This

\begin{tabular}{|c|c|c|c|c|c|c|c|}
\hline \multirow[b]{2}{*}{$\begin{array}{l}\text { Mothers' Assessment } \\
\text { after Delivery }\end{array}$} & \multirow[b]{2}{*}{ Group } & \multirow[b]{2}{*}{ Complete } & \multirow[b]{2}{*}{ Considerable } & \multirow[b]{2}{*}{ Slight } & \multirow[b]{2}{*}{ Nane } & \multicolumn{2}{|c|}{ Significance } \\
\hline & & & & & & $\begin{array}{l}\text { Complete v. All } \\
\text { Other Replies }\end{array}$ & $\begin{array}{l}\text { Complete and } \\
\text { Considerable } v \text {. } \\
\text { All Other Replies }\end{array}$ \\
\hline At $15 \mathrm{~min}$. & $\begin{array}{l}0.35 \\
0.25\end{array}$ & $\begin{array}{c}10(43 \%) \\
3(15 \%)\end{array}$ & $\begin{array}{l}13(57 \%) \\
15(75 \%)\end{array}$ & $\begin{array}{ll}0 & (0 \%) \\
1 & (5 \%)\end{array}$ & $\begin{array}{l}0(0 \%) \\
1(5 \%)\end{array}$ & $P=0.044$ & $P=0.21$ \\
\hline At $36-48$ hours & $\begin{array}{l}0.35 \\
0.25\end{array}$ & $\begin{array}{l}8(35 \%) \\
3(15 \%)\end{array}$ & $\begin{array}{l}15(65 \%) \\
13(65 \%)\end{array}$ & $\begin{array}{l}\mathbf{0}(0 \%) \\
3(15 \%)\end{array}$ & $\begin{array}{l}0(0 \%) \\
1(5 \%)\end{array}$ & $P=0.21$ & $P=0.0 .39$ \\
\hline
\end{tabular}


difference is significant. No mother having $0.35 \%$ methoxyflurane gave a grading lower than "considerable." In the 0.25 group the inhalation was stopped in one case after an hour because the mother complained of getting no pain relief.

Assessment of Pain Relief at 36-48 Hours after Delivery (Table V).-Four mothers of the 0.35 group changed their previous opinion-three from "complete" to "considerable" and one from "considerable" to "complete" pain relief. In the 0.25 group two mothers changed from " considerable" to "slight" pain relief. In this later assessment those replying "complete" or "considerable" are significantly more in the 0.35 group.

One patient in each group had to be excluded from some of the more detailed questions owing to language difficulties.

Other Questions at 15 Minutes after Delivery.-Drowsiness : Nine out of $22(43 \%)$ mothers in the 0.35 group and 7 out of $19(37 \%)$ in the 0.25 group said they felt drowsy. Sleep : Only one patient ( 0.35 group) felt herself "drifting off." Ability to Obey Commands : All patients felt able to do all that was asked of them during labour.

Other Questions at 36-48 Hours after Delivery.-Memory of Labour and Delivery (Table VI): There was little difference between the two concentrations with regard to memory for labour and delivery. Smell : $13(57 \%)$ of the mothers in the 0.35 group and $12(60 \%)$ in the 0.25 group noticed the smell ; only one ( 0.25 group) thought the smell unpleasant. Nausea and Vomiting : In the 0.35 group three mothers (13\%) felt nauseated during delivery and another three in the next 24 hours ; one of them (4\%) vomited. Altogether six (26\%) in the 0.35 group were affected. Only one patient in the 0.25 group felt sick, and that was during delivery ; none vomited. The difference between the two groups is nearly significant $(P=0.07)$.

TABLB VI.-Mothers' Memory of Labour and Delivery

\begin{tabular}{|c|c|c|c|c|c|c|}
\hline & & & \multirow{2}{*}{ Group } & \multicolumn{3}{|c|}{ Mothers' Memory } \\
\hline & & & & Clear & Hazy & None \\
\hline Labour & $\cdots$ & . & $\begin{array}{l}0.35 \\
0.25\end{array}$ & $\begin{array}{l}17(77 \%) \\
13(68 \%)\end{array}$ & $\begin{array}{l}5(23 \%) \\
6(32 \%)\end{array}$ & $\begin{array}{l}0(0 \%) \\
0(0 \%)\end{array}$ \\
\hline Delivery & .. & $\cdots$ & $\begin{array}{l}0.35 \\
0.25\end{array}$ & $\begin{array}{l}19(86 \%) \\
16(88 \%)\end{array}$ & $\begin{array}{l}2(9 \%) \\
2(12 \%)\end{array}$ & $\begin{array}{l}1(5 \%) \\
0(0 \%)\end{array}$ \\
\hline
\end{tabular}

- One patient excluded (caesarean section).

\section{Other Criteria}

Condition of Babies.-Of the babies in the 0.35 group $92 \%$ had an Apgar score at one minute of 8 or over; and $89 \%$ in the 0.25 group. The onset to regular respiration was within one minute in $84 \%$ of the 0.35 group and $88 \%$ of the 0.25 group. The differences are not significant. No baby required artificial ventilation.

Blood Loss. - The mean blood loss, assessed by the midwife, was $5 \mathrm{oz} .(142 \mathrm{ml}$.) in the 0.35 group and $8 \mathrm{oz}$. (227 ml.) in the 0.25 group. There was one postpartum haemorrhage of $40 \mathrm{oz}$. $(1,134 \mathrm{ml}$.) in the 0.25 group after a vacuum extraction.

Inhaled Concentrations. Vaporizer.-We intended the mothers to inhale a constant concentration of methoxyflurane. However, the wide variations in ventilation which occur during

TABLB VII.-Concentration of Methoxyflurane Delivered at Various

\begin{tabular}{|c|c|c|c|c|c|}
\hline \multicolumn{2}{|c|}{ Ventilation } & \multicolumn{4}{|c|}{ Concentrations Delivered by Vaporizer } \\
\hline \multirow{2}{*}{$\begin{array}{c}\text { Minute } \\
\text { Ventilation } \\
\text { (l./min.) }\end{array}$} & \multirow{2}{*}{$\begin{array}{c}\text { Tidal } \\
\text { Volume } \\
\text { (ml.) }\end{array}$} & \multicolumn{2}{|c|}{$0 \cdot 25 \%$ Setting } & \multicolumn{2}{|c|}{$0.35 \%$ Setting } \\
\hline & & $3 \mathrm{~min}$. & $30 \mathrm{~min}$. & $3 \mathrm{~min}$. & $30 \mathrm{~min}$. \\
\hline $\begin{array}{r}5 \\
10 \\
15 \\
20 \\
25 \\
30\end{array}$ & $\begin{array}{r}250 \\
500 \\
750 \\
750 \\
930 \\
1,100\end{array}$ & $\begin{array}{l}0.25 \% \\
0.25 \% \\
0.24 \% \\
0.21 \%\end{array}$ & $\begin{array}{l}0.25 \% \\
0.25 \% \\
0.24 \% \\
0.21 \%\end{array}$ & $\begin{array}{l}0.35 \% \\
0.35 \% \\
0.33 \% \\
0.33 \% \\
0.31 \% \\
0.29 \%\end{array}$ & $\begin{array}{l}0.35 \% \\
0.35 \% \\
0.33 \% \\
0.33 \% \\
0.31 \% \\
0.29 \%\end{array}$ \\
\hline
\end{tabular}

labour make this technically difficult to attain with any "drawover" vaporizer. We chose for the trial the vaporizer which gave us the most constant concentrations under simulated clinical conditions in the laboratory. The variations in concentration with these vaporizers at different minute ventilations are shown in Table VII. The uptake of methoxyflurane by the rubber hose was also investigated. The results show that a standard length of rubber breathing-tube has only a negligible effect on the inhaled concentration (S. C. Khataniar, personal communication, 1967).

Inhaled Concentrations. Ventilation.-Serial measurements of ventilation were made during contractions in 12 out of 23 in the 0.35 group and in 10 out of 20 in the 0.25 group. The ventilation during each contraction in the half-hour immediately preceding full dilatation was selected for study, since minute volume is greatest at the end of the first stage of labour (Reid, 1966). The ventilatory volumes in Table VIII were calculated from measurements made in the first 30 seconds of the contraction, since the majority of our patients stopped inhaling within 50 seconds of the onset of the contraction. None inhaled for less than 30 seconds. The mean and standard deviation for each patient and each group are shown in Table VIII. The distribution of all these measurements of ventilation is shown in Table IX.

TABLE VIII.-Mean Ventilation Per Minute Measured for 30 Seconds of Each Contraction in the Half-hour Preceding Full Dilatation

\begin{tabular}{|c|c|c|c|c|c|}
\hline \multirow{2}{*}{$\begin{array}{l}\text { Patients' } \\
\text { Code }\end{array}$} & \multicolumn{2}{|c|}{ Methoxyflurane $0.35 \%$} & \multirow{2}{*}{$\begin{array}{l}\text { Patients' } \\
\text { Code }\end{array}$} & \multicolumn{2}{|c|}{ Methoxyflurane $0.25 \%$} \\
\hline & $1 . / \mathrm{min}$. & $\begin{array}{l}\text { Standard } \\
\text { Deviation }\end{array}$ & & $1 . / \mathrm{min}$. & $\begin{array}{c}\text { Standard } \\
\text { Deviation }\end{array}$ \\
\hline $\begin{array}{l}\mathbf{A} \\
\mathbf{H} \\
\mathbf{N} \\
\mathbf{O} \\
\mathbf{S} \\
\mathbf{S} \\
\mathbf{F} \\
\mathbf{G} \\
\mathbf{T} \\
\mathbf{K} \\
\mathbf{U} \\
\mathbf{I}\end{array}$ & $\begin{array}{r}7.5 \\
7.7 \\
8 \cdot 1 \\
8.2 \\
11.7 \\
15.7 \\
16.4 \\
17.0 \\
17.5 \\
20.3 \\
20.9 \\
25.0\end{array}$ & $\begin{array}{l}0.40 \\
1.78 \\
1.11 \\
1.65 \\
1.64 \\
2.09 \\
2.02 \\
1.56 \\
1.31 \\
3.97 \\
2.94 \\
3.90\end{array}$ & $\begin{array}{l}\mathbf{R} \\
\mathbf{B} \\
\mathbf{Q} \\
\mathbf{P} \\
\mathrm{D} \\
\mathbf{E} \\
\mathrm{V} \\
\mathbf{M} \\
\mathrm{J} \\
\mathrm{L}\end{array}$ & $\begin{array}{r}8 \cdot 7 \\
9.7 \\
11.5 \\
12.8 \\
18 \cdot 6 \\
20 \cdot 4 \\
25 \cdot 3 \\
26 \cdot 2 \\
27 \cdot 1 \\
28 \cdot 6\end{array}$ & $\begin{array}{l}1.23 \\
1.04 \\
1.02 \\
2.11 \\
5.76 \\
5.24 \\
6.54 \\
5.92 \\
4.32 \\
5.17\end{array}$ \\
\hline Mean & \multicolumn{2}{|c|}{$14 \cdot 7 \pm 6 \cdot 03$} & Mean & \multicolumn{2}{|c|}{$18 \cdot 9 \pm 7 \cdot 72$} \\
\hline
\end{tabular}

$t$ test between two groups, $\mathrm{P}<0.20$.

TABLB IX.-Number of Measurements of Ventilation During Half-hour Preceding Full Dilatation

\begin{tabular}{|c|c|c|c|c|c|c|c|c|c|c|c|c|c|}
\hline \multirow{3}{*}{ Group } & \multicolumn{12}{|c|}{ No. of Measurements of Ventilation } & \multirow{3}{*}{$\begin{array}{l}\text { Total } \\
\text { No. }\end{array}$} \\
\hline & \multicolumn{2}{|c|}{$\stackrel{0 \rightarrow}{0 \rightarrow}$} & \multicolumn{2}{|c|}{$\underset{1 . / \mathrm{min} .}{10 \rightarrow}$} & \multicolumn{2}{|c|}{$\begin{array}{c}15 \rightarrow \\
1 . / \mathrm{min}\end{array}$} & \multicolumn{2}{|c|}{$\underset{1 . / \mathrm{min}}{20 \rightarrow}$} & \multicolumn{2}{|c|}{$1 . / \mathrm{min}}$. & \multicolumn{2}{|c|}{$\begin{array}{l}30 \rightarrow \\
1 . / \mathrm{min}\end{array}$} & \\
\hline & No. & $\%$ & No. & $\%$ & No. & $\%$ & No. & $\%$ & No. & $\%$ & No. & $\%$ & \\
\hline $\begin{array}{l}0.35 \\
0.25\end{array}$ & $\begin{array}{l}39 \\
13\end{array}$ & $\begin{array}{l}30 \\
13\end{array}$ & $\begin{array}{l}14 \\
20\end{array}$ & $\begin{array}{l}11 \\
19\end{array}$ & $\begin{array}{l}52 \\
14\end{array}$ & $\begin{array}{l}39 \\
14\end{array}$ & $\begin{array}{l}15 \\
26\end{array}$ & $\begin{array}{l}11 \\
25\end{array}$ & $\begin{array}{l}12 \\
15\end{array}$ & $\begin{array}{r}9 \\
15\end{array}$ & $\begin{array}{r}0 \\
14\end{array}$ & 14 & $\begin{array}{l}132 \\
102\end{array}$ \\
\hline Total & 52 & & 34 & & 66 & & 41 & & 27 & & 14 & & 234 \\
\hline
\end{tabular}

$\chi^{2}$ test, $\mathrm{P}<0.01$.

The difference seen between the two groups indicated that higher ventilations accompany the less satisfactory pain relief of $0.25 \%$. This difference is significant. This increase in ventilation is probably due to a mixture of a heightened respiratory response to pain and an attempt on the part of the patient to compensate for inadequate analgesia.

\section{Rejection of $\mathbf{0 . 4 5} \%$ Methoxyflurane}

Eight patients were given $0.45 \%$ methoxyflurane (mean duration of inhalation 1 hour 10 minutes; range 30 minutes to 2 hours). Five of the eight mothers (who had all received pethidine) were assessed as "very drowsy" by the anaesthetist. The mean percentage of time of inhalation during which the level of consciousness was deemed unsatisfactory in these eight patients was 17. We could not accept this high liability to drowsiness. Our opinion was confirmed by the midwives, who scored two of these patients as "too drowsy." Pain relief as 
assessed by the mothers was no better with this concentration than with $0.35 \%$. It became clear to us that a concentration of $0.45 \%$ methoxyflurane introduced no obvious benefit and was too strong for general use unless restrictions were to be placed on the duration of inhalation and perhaps on the use of pethidine.

\section{Discussion}

The mothers', the midwives', and the anaesthetist's assessments all demonstrated that $0.35 \%$ methoxyflurane is a better concentration than $0.25 \%$.

In our previous trial (Major et al., 1966) our aim was to vary the inhaled concentration for each mother until either there was no reaction to a contraction or she became too drowsy or restless. Therefore on theoretical grounds, because the inhaled concentration was carefully and continuously adapted for the needs of each patient (and must have been optimal), no improvement can be expected on the score recorded then for reaction to contraction. On the other hand, since in our first trial the methoxyflurane had to be "pushed" so as to assay its full potential value, there was inevitably a small incidence of side-effects. This must have reduced somewhat the best possible score for " all factors satisfactory." Our present trial of $0.35 \%$ methoxyflurane has equalled the original trial with regard to the score for reaction to contractions $(72.8$ and $71.8 \%)$, and has exceeded it for all factors satisfactory $(72.7$ and $60.3 \%)$. Since the percentage of time "satisfactory" for reaction to contractions with $0.35 \%$ methoxyflurane is the same as that achieved in our previous trial, and both a lower and a higher concentration proved less satisfactory, $0.35 \%$ must clearly be the optimum concentration. The mothers' and midwives' opinions of the $0.35 \%$ support the anaesthetist's assessments. In fact, they show a slight improvement on the results in the original trial.

Our conclusion about the optimum concentration is based on the administration of fixed known inhaled concentrations. We realized, however, that even the best temperaturecompensated "draw-over" vaporizer would not give an absolutely fixed concentration, owing to the high ventilation which commonly occurs during contractions. However, the effects of any ventilatory changes are small with the vaporizer used in this trial. The maximum ventilation measured in our patients was about $30 \mathrm{l} / \mathrm{min}$. - that is, a change of about $100 \%$ from the mean ventilation. At this the inhaled concentration fell by only $17 \%$ - from 0.35 to $0.29 \%$ (Table VII). Even at the extreme of ventilation measured in our patients this slight fall in inhaled concentration has a relatively small effect on the alveolar concentration, because of the large increase in the coincidental and causative minute volume (Mushin and Galloon, 1960).

Our recommended concentration of $0.35 \%$ methoxyflurane is less than that reported by other workers. Bodley et al. (1966), using a reputed $0.5 \%$ methoxyflurane from a Cyprane A.E. vaporizer, found that $82.2 \%$ of mothers thought the pain relief complete or adequate. However, $12.7 \%$ were uncooperative as judged by the anaesthetist-observer. Johnstone (1963), using an uncompensated vaporizer with " $0.5 \%$," found the analgesia inadequate, but 4 out of $25(16 \%)$ of his patients were too sleepy to co-operate in the second stage. Canadian and American workers (Romagnoli and Korman, 1962 ; Savel et al., 1967) also used an uncompensated inhaler-the Cyprane -at the setting recommended by Messrs. Abbott in their literature. Holl and Shnider (1967) have shown that the Cyprane vaporizer gives an inital concentration of $1 \%$, falling in a few minutes to between 0.4 and $0.5 \%$, and that general anaesthesia may develop. It is important to stress that our own results were achieved with a virtually constant inhaled concentration from a vaporizer well compensated for temperature and over a wide range of ventilation. It is clear from our trial that a change in inhaled concentration of $0.1 \%$, which may appear small, does in fact make a great difference to the results.

Our ultimate aim is to determine whether methoxyflurane is suitable for administration by unsupervised midwives. We therefore observed strict criteria in seeking for a concentration which would not only give a degree of analgesia at least as good as that commonly attained with trichloroethylene, but in addition would ensure full co-operation of the mother during delivery-not always a feature of existing methods. 'The value of methoxyflurane depends on whether this is possible: the results of our studies indicate that it is. Furthermore, the quality of the pain relief appears to be quite different from that seen with either trichloroethylene or nitrous oxide. The mother lies quietly, looking well sedated but quite able to co-operate. Many mothers comment spontaneously that they feel detached from the process of labour and that any pain seems remote.

The only side-effects of note were nausea and vomiting, well known to occur in association with labour. The incidence of these in our trial ( 0.35 group), bearing in mind that our inquiries extended for 24 hours after delivery, was comparable to that observed in connexion not only with methoxyflurane but with other analgesics as well (Johnstone, 1963 ; McAneny and Doughty, 1963 ; Bodley et al., 1966 ; Ransom, 1966).

Our initial experimental study was concerned with developing a screening method to ascertain the value of methoxyflurane as a self-administered obstetric analgesic. The method has clearly proved able to produce reliable predictions about the intermittent use of methoxyflurane and of the concentration required. In addition, it has done so with remarkable economy of patients. Now that we have established that methoxyflurane has attractive qualities as an obstetric analgesic we believe that it should be given a wide field trial. This we propose to do.

\section{Summary}

The present investigation has confirmed the value of our previously published method for screening obstetric analgesics from which we predicted that $0.35 \%$ met:oxyflurane would prove suitable for intermittent self-administration during labour.

Fixed inhaled concentrations of $0.35 \%$ and $0.25 \%$ methoxyflurane in air, from carefully calibrated thermo-compensated vaporizers, were compared. The results were assessed by an anaesthetist, by the mother, and by the midwife. All these assessments indicate that $0.35 \%$ is significantly better than $0.25 \%$ methoxyflurane. A higher concentration introduces an unacceptable degree of drowsiness. A field trial is now in progress.

We wish to thank our obstetric colleagues and the midwives at the Maternity Unit, St. David's Hospital, Cardiff, for their enthusiastic help and collaboration during this trial. We would also like to acknowledge the useful comments and criticisms of W. W. Mapleson, Ph.D., and of many other colleagues. This work was partially supported by a grant from Abbott Laboratories Ltd. The vaporizers were kindly presented by Longworth Scientific Ltd. (Penlon).

\section{REFERENCES}

Bodley, P. O., Mirza, V., Spears, J. R., and Spilsbury, R. A. (1966). Anaesthesia, 21, 457.

Holl, J. W., and Shnider, S. M. (1967). Anesthesiology, 28, 770.

Johnstone, M. (1963). Proceedings of the Symposium on Methoxyflurane, p. 35. Queenborough. Kent.

McAneny, T. M., and Doughty, A. G. (1963). Anaesthesia, 18, 488. Maior, V., Rosen, M., and Mushin, W. W. (1966). Brit. med. 7., 2, 1554. Major, V., Rosen, M., and Mushin, W. W. (1966). Brit. med. F., 2, 245 Mushin, W. W., and Galoon, S. (1960).
Ransom, S. (1966). Anaesthesia, 21, 464.

Ransom, S. (1966). Anaesthesia, 21, 464
Reid. D. H. S. (1966). Lancet, 1, 784.

Romagnoli, A., and Korman, D. (1962). Canad. Anaesth. Soc. 7., 9. 414. Savel, L., Kortis, H., Seitzman, I.., and Fleischer, J. (1967). Scientific Exhihition at 15 th Annual Meeting of American College of Obstetrics and Gynecology. Washington, D.C. 